\title{
Extracellular HIV-1 Tat enhances monocyte adhesion by up-regulation of ICAM-1 and VCAM-1 gene expression via ROS-dependent NF-kB activation in astrocytes
}

\author{
Ha Yong Song', Jiyoon Ryu', \\ Sung Mi Ju${ }^{1}$, Lee Jin Park', \\ Ji Ae Lee ${ }^{1}$, Soo Young $\mathrm{Choi}^{1,2}$ and \\ Jinseu Park ${ }^{1,2,3}$ \\ ${ }^{1}$ Department of Biomedical Science \\ Hallym University \\ Chuncheon 200-702, Korea \\ ${ }^{2}$ Research Institute for Bioscience and Biotechnology \\ College of Natural Sciences, Hallym University \\ Chuncheon 200-702, Korea \\ ${ }^{3}$ Corresponding author: Tel, 82-33-248-2116; \\ Fax, 82-33-256-3420; E-mail, jinpark@hallym.ac.kr
}

Accepted 28 November 2006

Abbreviations: ADC, AIDS dementia complex, ICAM-1, intercellular adhesion molecule-1; ROS, reactive oxygen species; Tat, transactivator of transcription; VCAM-1, vascular cell adhesion molecule-1

\begin{abstract}
One of characteristic features of AIDS-related ence phalitis and dementia is the infiltration of monocytes into the CNS. HIV-1 Tat was demonstrated to facilitate monocyte entry into the CNS. In this study, we examined the effect of HIV-1 Tat on the expression of adhesion molecules, generation of reactive oxygen species (ROS) and NF-KB activation in CRT-MG human astroglioma cells. Treatment of CRT-MG cells with HIV-1 Tat protein significantly increased protein and mRNA levels of ICAM-1 and VCAM-1, as measured by Western blot analysis and RT-PCR, in dicating that Tat increases these protein levels at an mRNA level. In addition, Tat induced the activation of NF-KB in astrocytes. Treatment of CRT-MG with $N F-\kappa B$ inhibitors led to decrease in Tat-induced protein and mRNA expression of ICAM-1 and VCAM1. Furthermore, HIV-1 Tat protein increased ROS generation. Inhibition of Tat-induced ROS generation by $\mathrm{N}$-acetyl cysteine, vitamin $\mathrm{C}$ and diphenyl iodonium suppressed Tat-induced NF- $\mathrm{K} B$ activation, ICAM-1 and VCAM-1 expression, and monocyte adhesion in CRT-MG. These data indicate that HIV-1 Tat can modulate monocyte adhesiveness by in-
\end{abstract}

creasing expression of adhesion molecules such as ICAM-1 and VCAM-1 via ROS- and NF-KB-dependent mechanisms in astrocytes.

Keywords: astrocytes; cell adhesion molecules; inflammation; intercellular adhesion molecule-1; NF$\kappa B$; reactive oxygen species; Tat protein, HIV-1; vascular cell adhesion molecule-1

\section{Introduction}

The most common neurological disorder associated with HIV infection is AIDS dementia complex (ADC) (Ozdener, 2005; Rumbaugh and Nath, 2006). Infiltration of monocytes into the CNS is an important step in the development of ADC. Although the precise mechanism by which monocytes infiltrate into the CNS during HIV disease progression is not yet understood, it is considered that abnormal expression of cell adhesion molecules and cytokine dysregulation facilitate the entry of the monocytes into the CNS (Weiss et al., 1999; Pu et al., 2003; D'Aversa et al., 2004). Blood-brain barrier (BBB) endothelial cells express adhesion molecules which mediate entry of monocyte into the CNS. Astrocytes, the major glial cells in the CNS and also one of major components of BBB, play an important role in leukocyte infiltration, acting as a source of chemokines, cytokines and adhesion molecules (for review, see Dong and Benveniste, 2001). When stimulated by pro-inflammatory cytokines (e.g., IL-1 and TNF$\alpha)$, astrocytes can express the increased level of adhesion molecules such as intercellular adhesion molecule-1 (ICAM-1) and vascular cell adhesion molecule-1 (VCAM-1), which can contribute to inflammatory events within the CNS.

The HIV-1 Tat (transactivator of transcription) protein is one of the viral gene products essential for the expression and replication of the viral genome (Morrow et al., 1994). Previous study demonstrated that Tat mRNA and protein were present in the brains of patients with ADC (Wiley et al., 1996; Hudson et al., 2000). This Tat protein, which can be secreted from the infected cells, has the ability to enter uninfected cells and exert its activity upon the responsive genes (Ensoli et al., 1993; Reviewed in Ref. Watson and Edwards, 1999). Therefore, HIV-1 
Tat is considered as one of major regulators involved in HIV-associated pathologies including ADC. Previous studies have shown that HIV-1 Tat exerts its activity on the expression of various adhesion molecules including VCAM-1, endothelial leukocyte adhesion molecule-1 (ELAM-1) and ICAM-1 in human endothelial cells (Dhawan et al., 1997). We also previously reported that HIV-1 Tat protein induced VCAM1 expression in human umbilical vein endothelial cells (HUVECs) (Park et al., 2000). In addition, HIV-1 Tat has been shown to induce expression of adhesion molecules such as VCAM-1 and ICAM-1 in astrocytes and increase monocyte binding to astrocytes (Woodman et al., 1999). Previous observations indicated that astrocytic adhesion molecules were increased in HIV1-associated cognitive/motor complex (Seilhean et al., 1997). Therefore, HIV-1 Tat may be an important regulator in the trafficking of monocytes into the CNS which may contribute to the development of HIV1-associated dementia (Rappaport et al., 1999).

Oxidative stress has been implicated in many aspects of HIV disease pathogenesis, including the onset of dementia (Mollace et al., 2001; Pocernich et al., 2005). Involvement of oxidative stress in the development of ADC was suggested by demonstrating the presence of increased protein and lipid peroxidation in the brain and cerebrospinal fluid compared to HIV non-demented patients. HIV-1 Tat protein has been shown to induce oxidative stress directly and indirectly. Previous results demonstrated that the injection of HIV-1 Tat protein in the rat striatum induced increased oxidative modification of proteins in the brain (Aksenov et al., 2001). These data indicate that increased levels of reactive oxygen species (ROS) in the brain can induce neuronal damage that leads to neurodegeneration. ROS can also act as second messengers in the intracellular signaling pathways involved in expression of many cellular genes such as matrix metalloproteinases (Schulze-Osthoff et al., 1997; Brenneisen et al., 2002).

Further understanding of the role of ROS generation in Tat mediated infiltration of monocyte into the CNS might help to develop a therapeutic tool for ADC. While it has been reported that Tat may generate ROS, the possible roles of ROS involved in Tat-induced ICAM-1 expression have not been studied. In this study, we further examined the molecular mechanism responsible for HIV-1 Tat-induced expression of adhesion molecules such as ICAM-1 and VCAM-1, and subsequent monocyte adhesion by astrocyte. We show that HIV-1 Tat increased the intracellular level of ROS which is involved in the translocation of NF- $\mathrm{KB}$ and subsequent expression of adhesion molecules and monocyte adhesion in human astrocytes.

\section{Materials and Methods}

\section{Cell culture}

CRT-MG human astroglial cells and THP-1 human monocytic cells were maintained in RPMI 1640 medium supplemented with $10 \%$ (v/v) heat-inactivated FBS, penicillin $\mathrm{G}(100 \mathrm{U} / \mathrm{ml})$, streptomycin $(100 \mu \mathrm{g} / \mathrm{ml})$ and L-glutamine $(2 \mathrm{mM})$ at $37^{\circ} \mathrm{C}$ in a humidified atmosphere containing $5 \% \mathrm{CO}_{2}$ and $95 \%$ air (Choi et al., 2002; Park et al., 2003).

\section{Reagents}

$N$ - $\alpha$-p-tosyl-L-lysine chloromethyl ketone hydrochloride (TLCK), diphenyl iodonium (DPI), vitamin C (L-ascorbic acid) and 2',7'-dichlorofluorescin diacetate (DCF-DA) were obtained from Sigma (St. Louis, MO). N-Acetyl-L-cysteine (NAC) and BAY 11-7082 were purchased from Calbiochem (La Jolla, CA). Calcein acetoxymethyl ester (calcein-AM) was purchased from Molecular Probe (Eugene, OR). Primary antibodies to ICAM-1, VCAM-1, actin and p65 were supplied by Santa Cruz (Santa Cruz, CA). HRP-conjugated anti-rabbit or goat antibodies were supplied by Sigma (St. Louis, MO).

\section{Purification of recombinant HIV-1 Tat protein}

Recombinant protein containing an 86 amino acids of HIV-1 Tat at the $C$ terminus and six histidine residues at the $\mathrm{N}$-terminus was purified by $\mathrm{Ni}^{2+}$ affinity chromatography under native conditions as described previously (Park et al., 2000). The Tat preparation eluted from column was subjected to a Detoxi-Gel Endotoxin Removing Gel (Pierce, Rockford, IL) to remove endotoxin. The purified Tat protein dissolved in $7 \mathrm{mM}$ DTT and $20 \%$ glycerol was aliquoted and stored at $-80^{\circ} \mathrm{C}$. The protein concentration was determined with Bradford protein assay (Bio-Rad) by using BSA as a standard. The integrity and purity of the HIV-1 Tat proteins were assessed by SDS-PAGE followed by Coomassie blue staining. The biological activity of Tat was confirmed by a transactivation assay in HeLa cells transfected with a plasmid containing an HIV long terminal repeat (LTR)-luciferase gene. Endotoxin levels for the Tat preparation were below the detection limit $(<0.1 \mathrm{EU} / \mathrm{ml})$ as tested by Limulus Amoebocyte Lysate assay (BioWhitaker, Walkersville, MD).

\section{Western blot analysis}

Cell lysates were prepared by lysing monolayer cells on a six-well plate with a lysis buffer containing 125 $\mathrm{mM}$ Tris- $\mathrm{HCl}, \mathrm{pH} 6.8,2 \%$ SDS, $10 \% \mathrm{v} / \mathrm{v}$ glycerol. Fifteen micrograms of the protein from each whole 
cell lysate were fractionated by electrophoresis on $10 \%$ SDS-polyacrylamide gel. Proteins were electrotransferred to a nitrocellulose membrane, which was then blocked with $10 \%(\mathrm{w} / \mathrm{v})$ dry milk in PBS. The membrane was probed with rabbit anti-VCAM-1 polyclonal antibody or rabbit anti-ICAM-1 polyclonal antibody diluted $1: 1,000$, followed by incubation with horseradish peroxidase-conjugated secondary antibodies diluted 1:10,000. The bound antibodies were visualized by enhanced chemiluminescence (ECL; Amersham) as recommended by the manufacturer. The same membrane was stripped and reprobed with an anti-actin antibody (internal control).

\section{Reverse transcription-PCR analysis}

Total RNA was isolated from CRT-MG cells using a Trizol reagent kit (Invitrogen, Gaithersburg, MD) according to the manufacturer's instructions (Zhang et al., 2005). The RNA $(2 \mu \mathrm{g})$ was reversibly transcribed with $10,000 \mathrm{U}$ of reverse transcriptase and $0.5 \mu \mathrm{g} / \mu \mathrm{l}$ oligo-(dT)15 primer (Promega, Madison, WI). PCR amplification of cDNA aliquots was performed with the following sense and antisense primers $\left(5^{\prime} \rightarrow 3^{\prime}\right)$ : VCAM-1 sense, ATGCCTGGGAAGATGGTCGTGA; VCAM-1 antisense, TGGAGCTGGTAGACCCTCGTG; ICAM-1sense, GGTGACGCTGAATGGGGTTCC; ICAM-1 antisense, GTCCTCATGGTGGGGCTATGACTC; beta-actin sense, GCGGGAAATCGTGCGTGACATT; and beta-actin antisense, GATGGAGTTGAAGGTAGTTTCGTG. PCR was performed in $50 \mu$ of $10 \mathrm{mmol} / \mathrm{l}$ Tris- $\mathrm{HCl}(\mathrm{pH}$ 8.3), $25 \mathrm{mmol} / \mathrm{l} \mathrm{MgCl} 2,10 \mathrm{mmol} / \mathrm{l} \mathrm{dNTP}, 100 \mathrm{U}$ of Taq DNA polymerase, and $0.1 \mu \mathrm{mol} / / \mathrm{l}$ of each primer and was terminated by heating at $70^{\circ} \mathrm{C}$ for $15 \mathrm{~min}$. PCR products were resolved on a $1 \%$ agarose gel and visualized with UV light after ethidium bromide.

\section{Measurement of intracellular ROS levels}

Intracellular ROS levels were determined using DCF-DA, which is converted by ROS into fluorescent DCF. CRT-MG cells $\left(1 \times 10^{5}\right.$ cells $)$ were maintained in serum free media for $16 \mathrm{~h}$, and then treated with HIV-1 Tat protein $(100 \mathrm{ng} / \mathrm{ml}$ to $1 \mu \mathrm{g} / \mathrm{ml})$ for varying time periods ( $5 \mathrm{~min}$ to $24 \mathrm{~h}$ ). To investigate the effect of NAC, DPI and vitamin C on HIV-1 Tat-induced ROS production, CRT-MG cells were incubated in the absence or presence of these inhibitors for $1 \mathrm{~h}$, and then treated with HIV-1 Tat protein $(500 \mathrm{ng} / \mathrm{ml})$ for $15 \mathrm{~min}$. Cells were washed twice with PBS and incubated with DCF-DA $(10 \mu \mathrm{M})$ for $30 \mathrm{~min}$. The cellular fluorescent images were obtained using a Zeiss Axiovert S100 microscope with a confocal laser-scanning system (Bio-Rad MRC-1024ES) by using laser excitation at $494 \mathrm{~nm}$ as previously described (Park et al., 2004).

\section{NF-kB protein localization}

The NF- $\kappa$ B p65 nuclear localization was detected by indirect immunofluorescence assay using confocal microscopy as described previously (Kim et al., 2003). Briefly, CRT-MG cells grown on a glass slide in a 12-well plate were treated with HIV-1 Tat for $1 \mathrm{~h}$. After being washed in PBS, the cells were fixed with $4 \%$ ice-cold formaldehyde for $30 \mathrm{~min}$ and permeablized with $0.2 \%$ Triton X-100. Rabbit polyclonal antibody to human NF-кB p65 (1:500) was applied for $1 \mathrm{~h}$ followed by incubation with fluorescein isothiocyanate-conjugated goat anti-rabbit $\lg$ (1:500) for $1 \mathrm{~h}$. The cells were transferred to a chamber on the stage of a Zeiss Axiovert S100 microscope and observed with a confocal laser-scanning system (Bio-Rad MRC-1024ES). The fluorescence images (excitation $494 \mathrm{~nm} /$ emission $518 \mathrm{~nm}$ ) of the cells were recorded every $0.25 \mathrm{~s}(\times 640)$.

\section{Nuclear extract preparation}

Nuclear protein extracts were prepared using a detergent lysis procedure from CRT-MG cells to assay the nuclear translocation of NF-kB. Cells were lysed in a buffer of $10 \mathrm{mM}$ HEPES (pH 7.9), $10 \mathrm{mM}$ $\mathrm{KCl}, 0.1 \mathrm{mM}$ EDTA, $1 \mathrm{mM}$ DTT, $0.5 \mathrm{mM}$ PMSF and $6.25 \%$ Nonidet P-40 (NP-40) on ice for $10 \mathrm{~min}$. Proteins were extracted from nucleus pellets by

$\mathbf{A}$

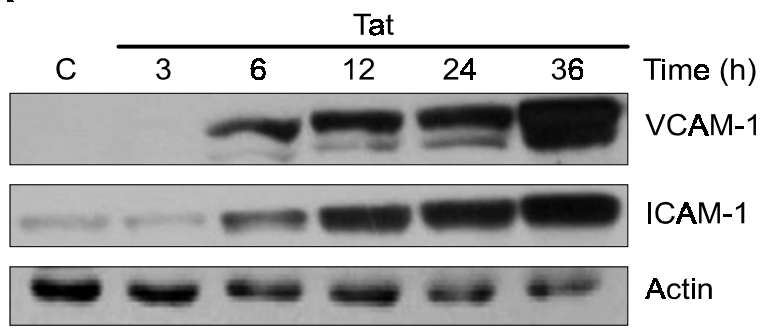

B

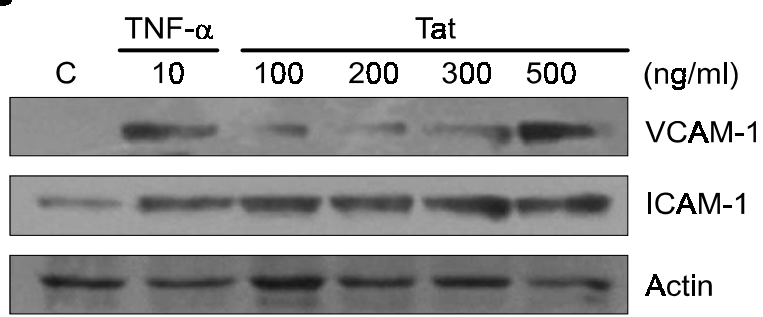

Figure 1. Induction of VCAM-1 and ICAM-1 protein expression in CRT-MG cells by HIV-1 Tat protein. CRT-MG cells were treated with $500 \mathrm{ng} / \mathrm{ml}$ HIV-1 Tat protein for varying times (A) and various concentration of HIV-1 Tat protein for $12 \mathrm{~h}(\mathrm{~B})$. Cell extracts were prepared and analyzed for VCAM-1 and ICAM-1 protein expression. Actin protein was used as an internal control. TNF- $\alpha(10 \mathrm{ng} / \mathrm{ml}$ for $12 \mathrm{~h})$ was used as a positive control. 
incubation with a high-salt buffer containing $0.4 \mathrm{M}$ $\mathrm{NaCl}, 20 \mathrm{mM}$ HEPES (pH 7.9), 1 mM EDTA, $1 \mathrm{mM}$ DTT, $1 \mathrm{mM}$ PMSF, 1\% NP-40 with vigorous shaking. The nuclear debris was pelleted by a brief centrifugation $(13,000 \mathrm{rpm}$ for $10 \mathrm{~min})$ and the supernatant was stored at $-70^{\circ} \mathrm{C}$. For the determination of $\mathrm{NF}-\kappa \mathrm{B}$ localization, Western blot analysis was carried out with nuclear protein extracts using anti-human NF-кB primary antibody $(1: 1,000)$. The Western blot analytical procedures were described above.

\section{Electrophoretic mobility shift assay (EMSA)}

CRT-MG cells were treated with HIV-1 Tat (500 $\mathrm{ng} / \mathrm{ml}$ ) for $1 \mathrm{~h}$, then nuclear extracts of CRT-MG cells were prepared and analyzed for $N F-\kappa B$ binding activity by EMSA as described previously (Park et al., 2003; 2004). An NF-kB consensus oligonucleotide (Promega) was used in the EMSA. The complementary oligonucleotide was annealed and endlabeled with $\left[\alpha^{-32}\right.$ P]ATP using T4 polynucleotide kinase. EMSA was performed in a total volume of 20 $\mu \mathrm{l}$ at $4^{\circ} \mathrm{C}$. Five micrograms of nuclear extracts were equilibrated for $15 \mathrm{~min}$ in binding buffer $(10 \mathrm{mM}$ Tris- $\mathrm{HCl}, \mathrm{pH} 8.0,75 \mathrm{mM} \mathrm{KCl}, 2.5 \mathrm{mM} \mathrm{MgCl}, 0.1$ $\mathrm{mM}$ EDTA, $10 \%$ glycerol, $0.25 \mathrm{mM}$ dithiothreitol) and $1 \mu \mathrm{g}$ of poly $\mathrm{dl} / \mathrm{dC}$. ${ }^{32} \mathrm{P}$-labeled oligonucleotide probe $(20,000 \mathrm{cpm})$ was then added and the reaction was incubated on ice for an additional $20 \mathrm{~min}$. Bound and free DNA were then resolved by electrophoresis on a $6 \%$ native polyacrylamide gel in TBE buffer (89 $\mathrm{mM}$ Tris- $\mathrm{HCl}, 89 \mathrm{mM}$ boric acid, and $2 \mathrm{mM}$ EDTA).

A

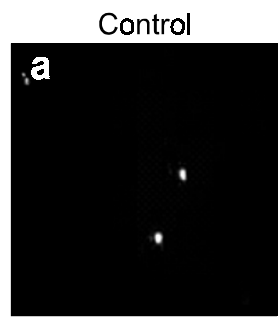

B

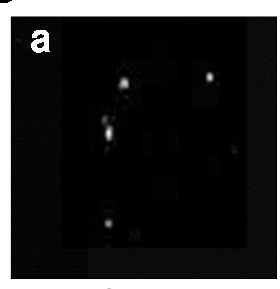

Control

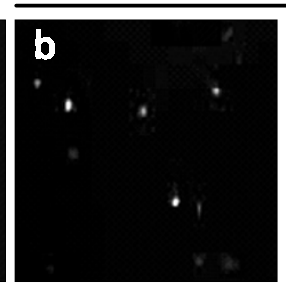

$100 \mathrm{ng} / \mathrm{ml}$
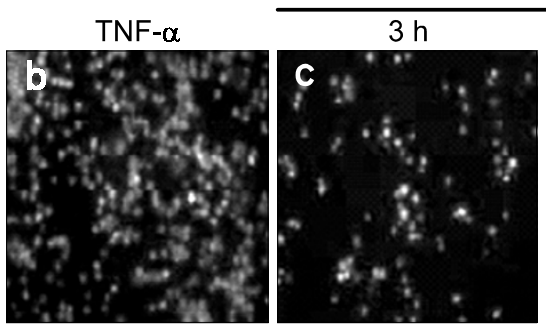

Tat
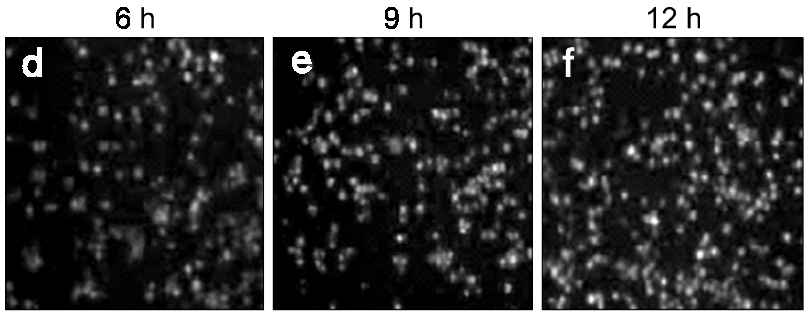

Tat $12 \mathrm{~h}$

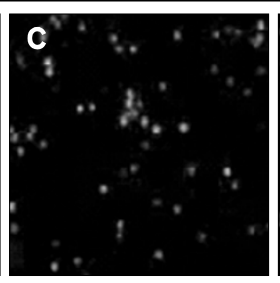

$200 \mathrm{ng} / \mathrm{ml}$

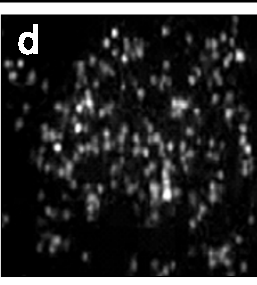

$500 \mathrm{ng} / \mathrm{ml}$

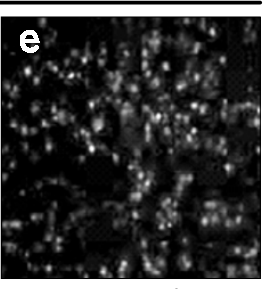

$1,000 \mathrm{ng} / \mathrm{ml}$

C

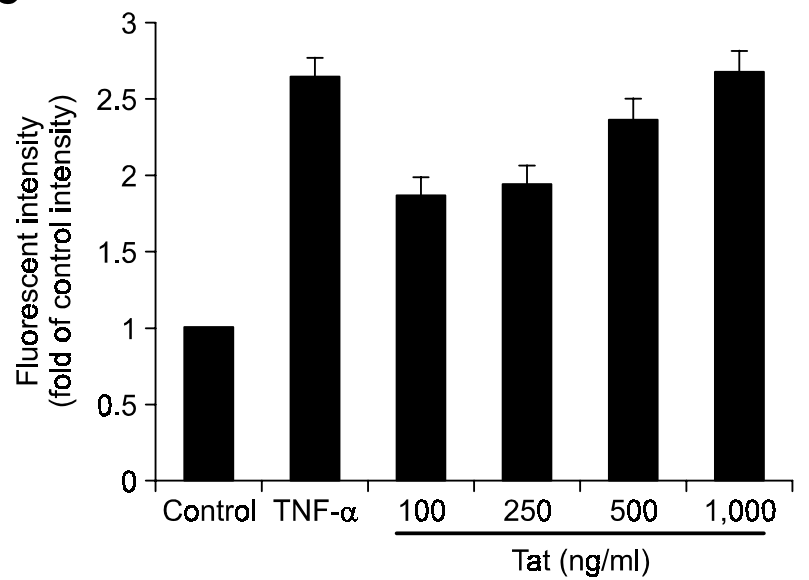

Figure 2. Induction of monocyte adhesion to CRT-MG cells by HIV-1 Tat protein. (A) time- and (B) dose-dependancy of monocytes adhesion to CRT-MG cells induced by HIV-1 Tat protein. CRT-MG cells were treated with $500 \mathrm{ng} / \mathrm{ml} \mathrm{HIV-1}$ Tat protein for various times and various concentrations of HIV-1 Tat protein for $12 \mathrm{~h}$. CRT-MG cells were cocultured with calcein-AM-labeled THP-1 monocytes. Microphotographs were obtained using fluorescence microscopy (original magnification, $\times 40$ ). (C) The calcein-AM fluorescent intensity was measured by an ELISA plate reader. Values are means \pm SEM, $n=3$. TNF- $\alpha(10 \mathrm{ng} / \mathrm{ml}$ for $12 \mathrm{~h}$ ) was used as positive control. 


\section{Cell adhesion assay}

Adherence of THP-1 cells to CRT-MG cells was assayed using a cell-cell adhesion assay as described elsewhere (Choi et al., 2004). Briefly, CRTMG cells were cultured at a density of $7.0 \times 10^{4}$ cells on a 24-well glass chamber slide. CRT-MG cells were pre-treated with the various antioxidants (20 mM NAC, $10 \mu \mathrm{M}$ DPI, $10 \mu \mathrm{M}$ vitamin C) and NF- $\kappa$ B inhibitors (100 $\mu \mathrm{M}$ TLCK, $1 \mu \mathrm{M}$ BAY 11-7082) for $1 \mathrm{~h}$ and followed by exposure to HIV-1 Tat protein $(500 \mathrm{ng} / \mathrm{ml})$ for $12 \mathrm{~h}$. CRT-MG cells were washed three times with PBS before cell-cell adhesion assay. THP-1 cells were labeled for $30 \mathrm{~min}$ with 5 $\mu \mathrm{mol} / \mathrm{l}$ calcein-AM (Molecular Probes, Inc.). The labeled THP-1 $\left(7.0 \times 10^{5}\right)$ cells were co-cultured with CRT-MG cells for $1 \mathrm{~h}$. Co-cultured cells were washed three times with PBS. The fluorescence images were obtained at $485 \mathrm{~nm}$ excitation and 538 $\mathrm{nm}$ emission using a SPOT II digital camera-attached fluorescence microscope with Spot II data acquisition software (Diagnostic Instrument). For the adhesion quantification, the calcein-AM fluorescent intensity was measured at $485 \mathrm{~nm}$ excitation and $538 \mathrm{~nm}$ emission by a Fluoroskan ELISA plate reader (Labsystems Oy).

\section{Results}

HIV-1 Tat induces ICAM-1 and VCAM-1 expression and increases monocyte adhesion to astrocytes

HIV-1 Tat has been shown to induce expression of ICAM-1 and VCAM-1 in human astrocytes (Woodman et al., 1999), suggesting the possible role of HIV-1 Tat in infiltration of monocytes into the CNS, which is important in HIV pathogenesis. To better understand the molecular mechanisms underlying in HIV-1 Tat-induced ICAM-1 and VCAM-1 expression, we analyzed HIV-1 Tat induction of ICAM-1 and VCAM-1 expression in the human astrocytic cell line CRT-MG. HIV-1 Tat induced ICAM-1 and VCAM-1 expression in time- and dose-dependent manners (Figure $1 \mathrm{~A}$ and $\mathrm{B}$ ). Next, we examined the effect of HIV-1 Tat on monocyte adhesion to astrocytes. CRT-MG cells were treated with HIV-1 Tat, and then analyzed for monocyte adhesion to astrocytes. As shown in Figure 2, adhesion of monocytes to CRT-MG cells was significantly increased following HIV-1 Tat treatment of CRT-MG cells in time- and dose-dependent manners (Figure 2).

\section{HIV-1 Tat activates transcription of ICAM-1 and VCAM-1 gene in astrocytes}

To examine whether HIV-1 Tat activates transcription of ICAM-1 and VCAM-1 in CRT-MG cells, we ana- lyzed the induction of ICAM-1 and VCAM-1 mRNA expression in Tat-treated CRT-MG cells (Figure 3 ). Cells were treated with HIV-1 Tat and mRNA levels of ICAM-1 and VCAM-1 were measured by RT-PCR. As shown in Figure 3, time- and dose-dependent increase in levels of ICAM-1 and VCAM-1 mRNA was observed in CRT-MG cells following HIV-1 Tat treatment.

\section{NF- $\mathrm{KB}$ is responsible for induction of ICAM-1 and VCAM-1 expression by HIV-1 Tat in human astrocyte cells}

ICAM-1 and VCAM-1 expression is regulated by different transcription factors including $\mathrm{NF}-\kappa \mathrm{B}$ in astrocytes (Lee et al., 1998). Previous studies demonstrated that extracellular HIV-1 Tat protein is associated with an increase in NF- $\mathrm{KB}$ binding activity in primary human astrocytes (Conant et al., 1996). To examine the involvement of NF-KB in ICAM-1 and VCAM-1 expression and monocyte adhesion to astrocytes, CRT-MG cells were treated with HIV-1 Tat, and the translocation of $\mathrm{NF}-\kappa \mathrm{B}$ was monitored by indirect immunofluorescence. Nuclear accumulation of NF-kB p65 in HIV-1 Tat treated CRT-MG cells was strongly induced (Figure 4). Pharmacological NF- $\kappa B$
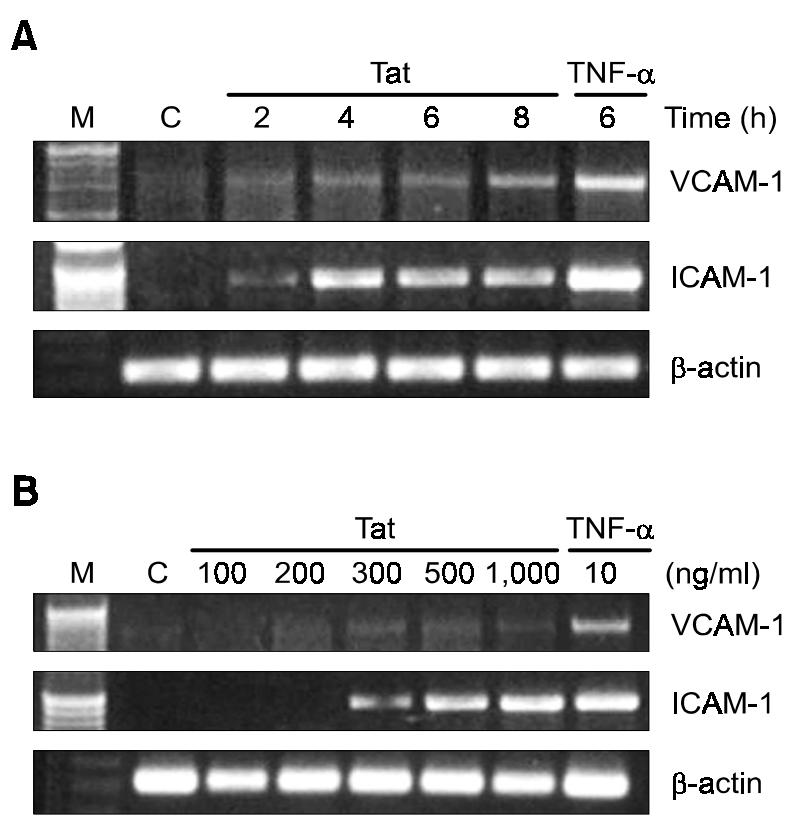

Figure 3. Induction of VCAM-1 and ICAM-1 gene expression in CRT-MG by HIV-1 Tat protein. CRT-MG cells were treated with 500 $\mathrm{ng} / \mathrm{ml} \mathrm{HIV-1}$ Tat protein for various times (A) and various concentrations of HIV-1 Tat protein for $8 \mathrm{~h}$ (B). Total RNA was extracted. VCAM-1, ICAM- 1 and $\beta$-actin mRNA were quantitated by RT-PCR using specific primers. RT-PCR products were analyzed by $1 \%$ agarose gel electrophoresis. TNF- $\alpha$ (10 ng/ml for $6 \mathrm{~h}$ ) was used as positive control. 
A

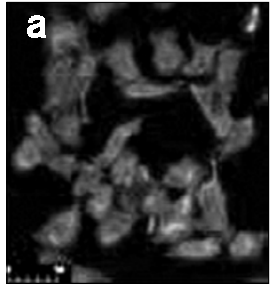

Control

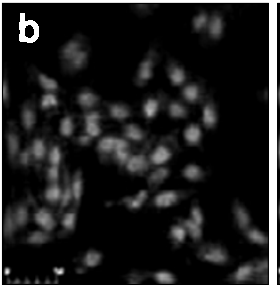

TNF- $\alpha$

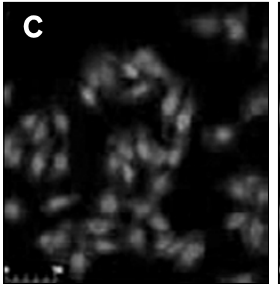

Tat

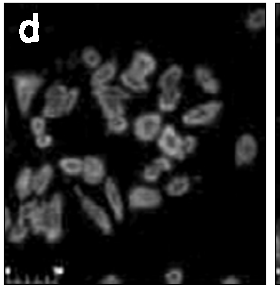

TLCK/Tat

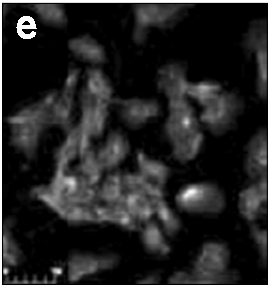

BAY/Tat

B

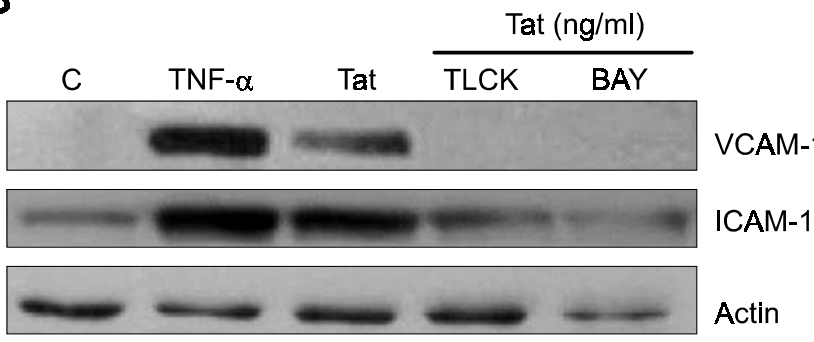

C

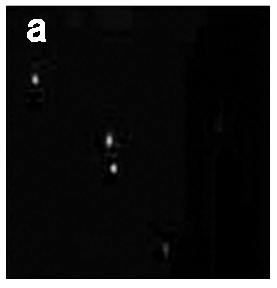

Control

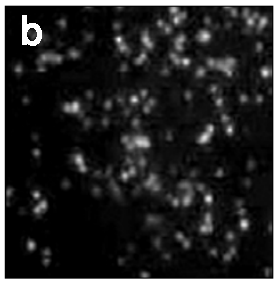

TNF- $\alpha$

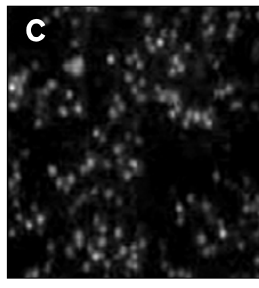

Tat

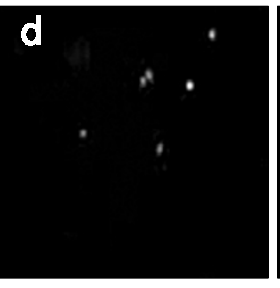

TLCK/Tat

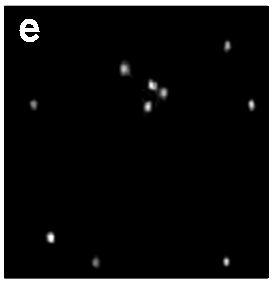

$\mathrm{BAY} / \mathrm{Tat}$

Figure 4. NF-KB dependancy of adhesion molecules (VCAM-1 and ICAM-1) expression and monocyte adhesion in CRT-MG cells induced by HIV-1 Tat protein. (A) CRT-MG cells were treated with HIV-1 Tat protein ( $500 \mathrm{ng} / \mathrm{ml})$ for $1 \mathrm{~h}$ with or

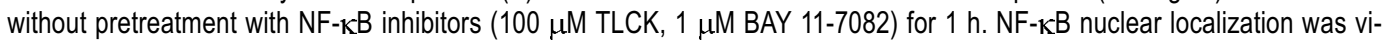
sualized with a confocal microscopy by indirect immunofluorescence using anti-NF-kB p65 antibody. TNF- $\alpha$ ( $10 \mathrm{ng} / \mathrm{ml}$ for 30 $\mathrm{min}$ ) was used as positive control. (B) CRT-MG cells were treated with HIV-1 Tat protein (500 ng/ml) for $12 \mathrm{~h}$ with or without pretreatment with NF-KB inhibitors (100 $\mu \mathrm{M}$ TLCK, $1 \mu \mathrm{M}$ BAY 11-7082) for $1 \mathrm{~h}$. Cell extracts were prepared and analyzed for VCAM-1 and ICAM-1 protein expression. (C) CRT-MG cells were treated with HIV-1 Tat protein $(500 \mathrm{ng} / \mathrm{ml})$ for $12 \mathrm{~h}$ with or without pretreatment with NF-KB inhibitors (100 $\mu \mathrm{M} \mathrm{TLCK}, 1 \mu \mathrm{M}$ BAY 11-7082) for $1 \mathrm{~h}$. CRT-MG cells were cocultured with calcein-AM-labeled THP-1 monocytes. Microphotographs were obtained using fluorescence microscopy (original magnification, $\times 40$ ).

inhibitors, TLCK, and BAY 11-7082, prevented Tatinduced translocation of $\mathrm{p} 65$. In addition, pretreatment with TLCK, or BAY 11-7082 suppressed Tatinduced expression of ICAM-1 and VCAM-1 protein (Figure 4B) and monocyte adhesion to CRT-MG cells (Figure $4 C$ ). These results indicate that Tatinduced NF- $\mathrm{kB}$ activity is necessary for inducing ICAM-1 and VCAM-1 expression in CRT-MG cells as well as monocyte adhesion to astrocytes.

\section{Generation of ROS by HIV-1 Tat in astrocyte cells}

Since NF-KB is one of redox-dependent transcription factors (Sen and Packer, 1996; Flohe et al., 1997),
ROS may be involved in Tat-induced increase of ICAM-1 and VCAM-1 expression by human astrocytes. We examined whether ROS can be generated in CRT-MG cells treated with HIV-1 Tat. After treatment with Tat for various time periods, CRT-MG cells were incubated with DCF-DA, which has been used as a general marker of intracellular ROS production (Park et al., 2004). As shown in Figure $5 \mathrm{~A}$, a time-dependent increase in ROS levels was observed in CRT-MG. ROS production was detected as early as $5 \mathrm{~min}$ and was maximal at $15 \mathrm{~min}$ after treatment with Tat. ROS production was induced in a dose-dependent manner by CRT-MG cells exposed to HIV-1 Tat $(100-1,000 \mathrm{ng} / \mathrm{ml}$ ) (Figure 5B). To 
A
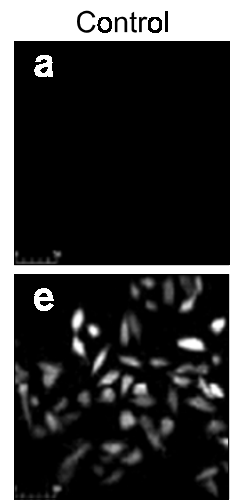

Tat/15 min

B

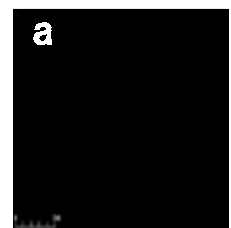

Control
$\mathrm{H}_{2} \mathrm{O}_{2}$
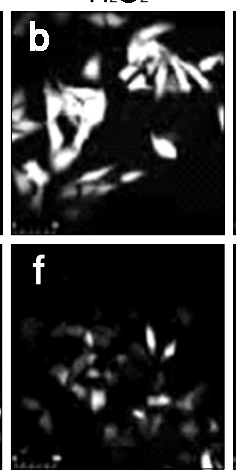

Tat/1 h
Tat/5 min
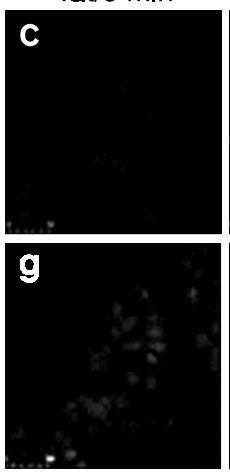

Tat/2 h
Tat/10 min
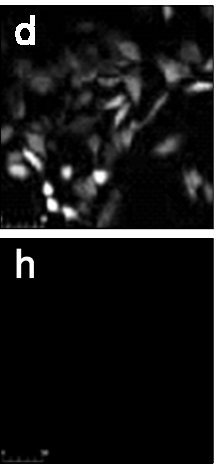

Tat/24 h
C
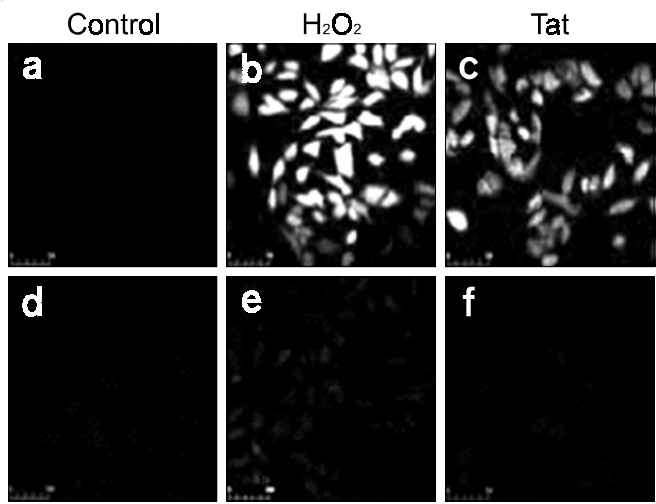

Tat/NAC

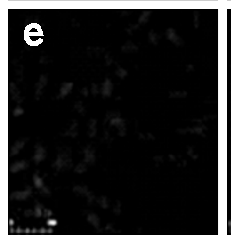

Tat/DPI

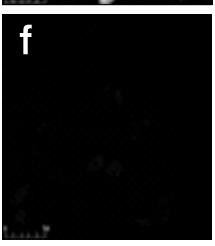

Tat/V.C

Tat

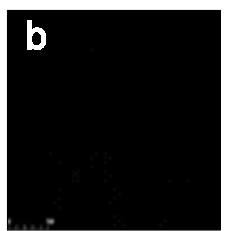

$100 \mathrm{ng} / \mathrm{ml}$

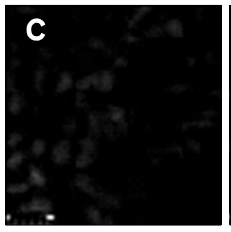

$200 \mathrm{ng} / \mathrm{ml}$

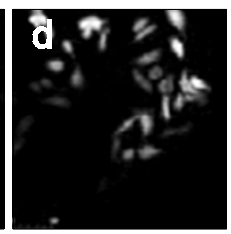

$500 \mathrm{ng} / \mathrm{ml}$

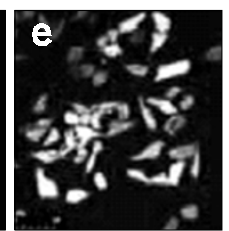

$1,000 \mathrm{ng} / \mathrm{ml}$

Figure 5. Analysis of ROS generation in the CRT-MG cells exposed to HIV-1 Tat protein. CRT-MG cells were treated with $500 \mathrm{ng} / \mathrm{ml}$ HIV-1 Tat protein for various times (A) and various concentrations of HIV-1 Tat protein for $1 \mathrm{~h}(\mathrm{~B})$. Intracellular ROS levels were measured after staining with DCF-DA. Visualization of the ROS of the treated cells was measured by confocal microscopy (original magnification, $\times 200$ ). To analyze the effect of NAC DPI and vitamin $C$ on HIV-1 Tat-induced ROS production, CRT-MG cells were pretreated with NAC (20 mM), DPI (10 $\mu \mathrm{M})$ or vitamin $\mathrm{C}(10 \mu \mathrm{M})$ for 1 $\mathrm{h}$, and incubated with HIV-1 Tat protein $(500 \mathrm{ng} / \mathrm{ml})$ for $1 \mathrm{~h}$ and then intracellular ROS were measured (C).

further characterize Tat-induced ROS production in CRT-MG cells, we utilized antioxidants, NAC, vitamin $\mathrm{C}$ and a flavoprotein inhibitor, DPI. DPI has been used widely to inhibit non-phagocytic NADPH oxidase (Cross and Jones, 1986; Doussiere and Vignais, 1992). Pretreatment with NAC, DPI and vitamin $C$ inhibited Tat-induced increase of intracellular ROS levels in CRT-MG cells (Figure $5 \mathrm{C}$ ). These results indicate that HIV-1 Tat induces generation of ROS in CRT-MG cells in time- and dose-dependent manners.

\section{ROS are responsible for HIV-1 Tat-induced activation of NF-KB and ICAM-1/VCAM-1 expression}

Next, we examined the possible role of ROS in Tat-induced nuclear translocation and DNA binding ability of NF-kB in CRT-MG cells. CRT-MG cells were incubated in the absence or presence of NAC, DPI or Vitamin C for $1 \mathrm{~h}$, followed by exposure to HIV-1 Tat $(500 \mathrm{ng} / \mathrm{ml})$ for $1 \mathrm{~h}$. Nuclear extracts were prepared and the nuclear translocation of $\mathrm{NF}-\kappa \mathrm{B}$ was analyzed by fluorescence microscopy and Western blot technique. In addition, nuclear extracts were used for mobility shift assays with a radioactive

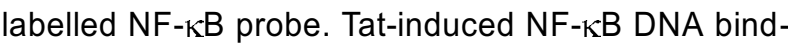
ing complex composed of primarily both p50 and p65, as analyzed by supershift assay using antibodies against the $\mathrm{NF}-\kappa \mathrm{B}$ subunits p50 and p65 (data not shown). As an indicator of NF-kB activation, p65 subunit was chosen and analyzed in confocal microscopy and Western blot analysis. As shown in Figure 6, pretreatment with NAC, DPI and vitamin C suppressed Tat-induced nuclear translocation (Figure 6A and 6B) as well as DNA binding activity (Figure $6 \mathrm{C}$ ) of NF-kB. We further used these inhibitors to analyze the role of ROS on Tat-induced up-regulation of ICAM-1 and VCAM-1 expression in CRT-MG cells. Cells were incubated in the absence or presence of DPI or NAC for $1 \mathrm{~h}$, treated with Tat (500 ng/ml), and then ICAM-1 and VCAM-1 expression was analyzed by RT-PCR and Western blot analysis. Pretreatment with DPI or NAC inhibited markedly ICAM-1 and VCAM-1 mRNA (Figure 7A) and protein (Figure 7B) expression.

\section{ROS are responsible for Tat-induced monocyte adhesion to astrocytes}

To further confirm the relevance between ROS 
A
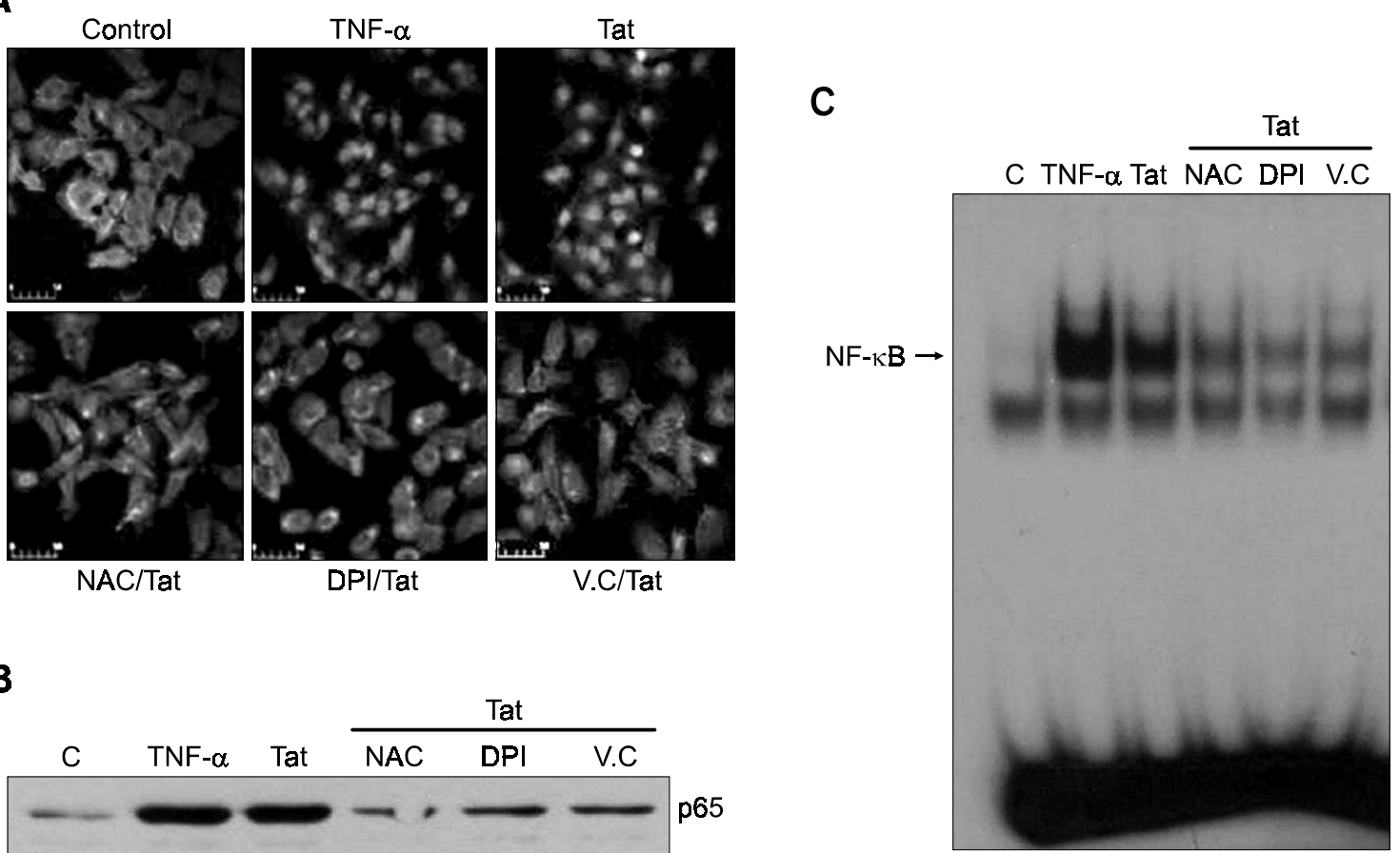

B

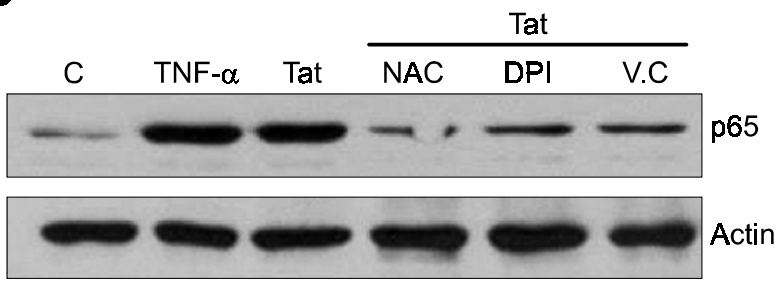

Figure 6. Effect of antioxidants on the NF-KB nuclear localization and DNA-binding activity in CRT-MG cells exposed to HIV-1 Tat protein. CRT-MG cells were treated with HIV-1 Tat protein $(500 \mathrm{ng} / \mathrm{ml})$ for $1 \mathrm{~h}$ with or without pretreatment with the various antioxidants (20 mM NAC, $10 \mu \mathrm{M} \mathrm{DPI}, 10 \mu \mathrm{M}$ vitamin C). NF-kB nuclear localization was visualized with a confocal microscopy by indirect immunofluorescence using anti-NF-kB p65 antibody (A). Nuclear extracts were prepared from the CRT-MG cells treated with HIV-1 Tat and the levels of $p 65$ were determined by Western blot analysis (B). DNA-binding activity of NF- $\mathrm{kB}$ in the nuclear extracts of the CRT-MG cells was measured by EMSA (C).

production and monocyte adhesion, we examined the effect of NAC, DPI or vitamin C on monocyte adhesion to CRT-MG cells. CRT-MG cells were incubated in the absence or presence of NAC, DPI or vitamin $C$ for $1 \mathrm{~h}$, treated with Tat $(500 \mathrm{ng} / \mathrm{ml})$, and then analyzed for monocyte adhesion to CRT-MG cells. As shown in Figure 8, adhesion between THP-1 and CRT-MG cells induced by HIV-1 Tat decreased significantly when the CRT-MG cells were pre-treated with NAC, DPI or vitamin C (Figure 8A and $B$ ). These results indicate that ROS is required for Tat-induced expression of ICAM-1 and VCAM-1 and subsequent adhesion of monocyte to astrocytes.

\section{Discussion}

HIV-1 Tat has been found to induce abnormal expression of cell adhesion molecules and cytokine dysregulation, which are believed to initiate the inflammation that causes damage in/of the CNS in patients with ADC (Rappaport et al., 1999). Elevated levels of Tat mRNA and protein in the brains of patients with ADC implicate that HIV-1 Tat is involved in HIV-associated pathologies including ADC (Wiley et al., 1996; Hudson et al., 2000). Intracerebral injection of HIV-1 Tat protein in the rat and the mouse resulted in infiltration of inflammatory cells, reactive astrogliosis, and neurotoxicity (Rappaport et al., 1999; Aksenov et al., 2001), demonstrating direct role of HIV-1 Tat in the CNS damage. Direct and indirect neurotoxic activities of HIV-1 Tat have been demonstrated in various in vivo and in vitro studies (Pocernich et al., 2005). Especially, up-regulation of expression of adhesion molecules such as ICAM-1 and VCAM- 1 by Tat may induce a series of interactions between monocytes, endothelial cells, and astrocytes, resulting in enhanced infiltration of monocytes into the CNS (Rappaport et al., 1999; Langford and Masliah, 2001). The molecular mechanism by which HIV-1 Tat induces expression of adhesion molecules such as ICAM-1 and VCAM-1 in 
A

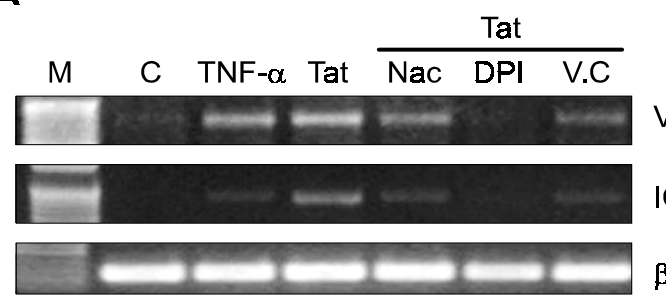

VCAM-1

ICAM-1

$\beta$-actin

B

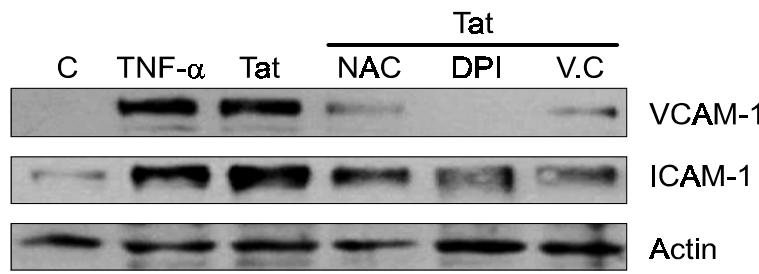

Figure 7. Effects of antioxidants on HIV-1 Tat-induced VCAM-1 and ICAM-1 expression in CRT-MG cells. A: CRT-MG cells were treated with $20 \mathrm{mM}$ NAC, $10 \mu \mathrm{M}$ DPI and $10 \mu \mathrm{M}$ vitamin $\mathrm{C}$ for $1 \mathrm{~h}$, then treated with HIV-1 Tat protein $(500 \mathrm{ng} / \mathrm{ml})$ for $8 \mathrm{~h}$. Total RNA was extracted. VCAM-1, ICAM- 1 and $\beta$-actin mRNA were analyzed by RT-PCR using specific primers. B: CRT-MG cells were treated with HIV-1 Tat protein $(500 \mathrm{ng} / \mathrm{ml})$ for $12 \mathrm{~h}$ with or without pretreatment with various antioxidants for $1 \mathrm{~h}$. Cell extracts were prepared and analyzed for VCAM-1 and ICAM-1 protein expression.

astrocyte has not been fully understood. In this study, we demonstrate that ROS generated by HIV-1 Tat mediates activation of $\mathrm{NF}-\kappa \mathrm{B}$, up-regulation of ICAM-1 and VCAM-1 and subsequent increased monocyte adhesion to astrocytes. Pretreatment of CRT-MG cells with antioxidants inhibited significantly Tat-induced NF- $\mathrm{B}$ B activation, ROS generation and subsequently expression of adhesion molecules, suggesting that prevention of ROS generation by Tat is one of strategies to control monocyte infiltration into the CNS.

Astrocytes can be induced by HIV-1 Tat as well as various proinflammatory cytokines such as TNF- $\alpha$ to express the adhesion molecules. Enhanced expression of adhesion molecules such as ICAM-1 on the surface of astrocytes is required for monocyte-astrocyte interaction which increases infiltration of monocytes into the CNS observed in the patients with HIV dementia (Wu et al., 2000). Our results are consistent with previous report that HIV-1 Tat increased monocyte binding to astrocyte by affecting expression of adhesion molecules such as ICAM-1 and VCAM-1 in astrocytes (Woodman et al., 1999; Pu et al., 2003). ICAM-1 and VCAM-1 are regulated primarily at the level of gene transcription upon a variety of stimuli. We showed that HIV-1 Tat-induced increase in ICAM-1 expression is regulated at the transcriptional level in an NF- $\mathrm{B}$-dependent path-
A
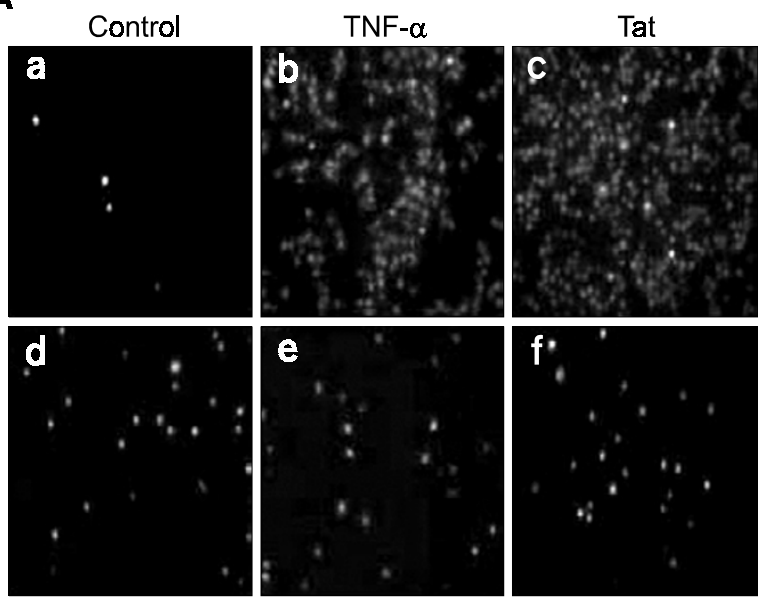

$\mathrm{NAC} / \mathrm{Tat}$

$\mathrm{DPI} / \mathrm{Tat}$

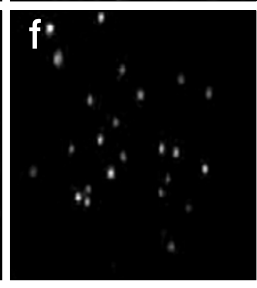

V.C/Tat

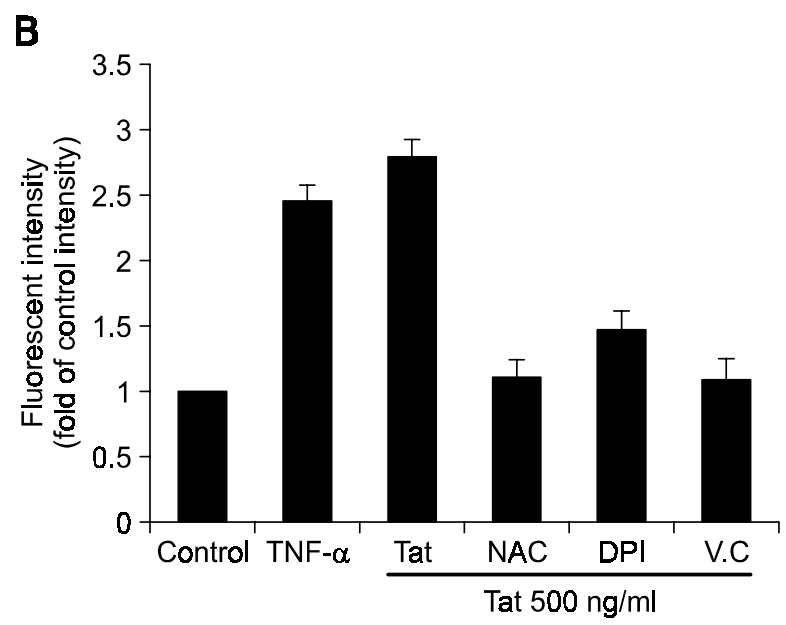

Figure 8. Inhibition of HIV-1 Tat-induced monocyte adhesion to CRT-MG by antioxidants. CRT-MG cells were treated with various antioxidants (20 mM NAC, $10 \mu \mathrm{M}$ DPI, $10 \mu \mathrm{M}$ vitamin C) for $1 \mathrm{~h}$ and followed by exposure to HIV-1 Tat protein $(500 \mathrm{ng} / \mathrm{ml})$ for $12 \mathrm{~h}$. CRT-MG cells were co-cultured with calcein-AM-labeled THP-1 monocytes. (A) Microphotographs were obtained using fluorescence microscopy (original magnification, $\times 40$ ). (B) The calcein-AM fluorescent intensity was measured by an ELISA plate reader. Values are means \pm SEM, $n$ $=3$.

way. NF-kB inhibitors inhibited the expression of ICAM-1 and VCAM-1 gene and monocyte adhesion to astrocyte in response to HIV-1 Tat via suppressing $N F-\kappa B$ activation (Figure 4), suggesting the functional relevance of Tat-mediated activation of $\mathrm{NF}-\kappa \mathrm{B}$. The molecular mechanism by which HIV-1 Tat induces NF-KB activation which is responsible for adhesion molecule expression such as ICAM-1 and VCAM-1, and subsequent monocyte adhesion on astrocyte is not clear. Conant et al. demonstrated that extracellular HIV-1 Tat protein is associated with $N F-\kappa B$ activation that is independent of new protein 
synthesis in primary human astrocytes (1996), suggesting the involvement of the possible signaling pathways that lead to the NF- $\kappa$ B activation.

We performed experiments to explore the mechanisms of NF- $\mathrm{KB}$ activation by HIV-1 Tat. As shown in Figure 5, ROS generation was induced following HIV-1 Tat treatment of astrocytes. Previous results indicate that HIV-1 Tat induces cellular oxidative stress which potentiates TNF-induced NF- $\mathrm{B}$ activation (Westendorp et al., 1995). ROS mediate many of the pathophysiological events that lead to development of several neurodegenerative disorders, including HIV-related dementia. HIV-1 Tat-induced NF- $\mathrm{KB}$ activation was significantly inhibited in the cells treated with HIV-1 Tat in the presence of antioxidants (Figure 6), indicating that HIV-1 Tat-mediated ROS generation was associated with activation of $N F-\kappa B$ in astrocytes. The functional role of ROS generation by Tat was demonstrated by our results showing that up-regulation of mRNA and protein expression of ICAM-1 and VCAM-1 diminished in the astrocytes treated with antioxidants. Furthermore, treatment of CRT-MG cells with antioxidants before exposure to HIV-1 Tat significantly inhibited monocyte adhesion to astrocyte. These results indicate that ROS is involved in the signal transduction pathway leading to activation of NF- $\mathrm{KB}$ and to NF- $\mathrm{KB}$-activated ICAM-1 and VCAM-1 expression in astrocytes. The exact mechanism by which HIV-1 Tat induces the generation of ROS in astrocyte is not clear. As shown in Figure 5C, HIV-1 Tat-induced generation of ROS was inhibited by DPI, suggesting that a NADPH oxidase is involved in the generation of ROS by Tat. Because DPI is not specific for NADPH oxidase, we can not rule out the involvement of non-NADPH oxidases in HIV-1 Tatinduced ROS generation. Further study is required to define the exact source of ROS generation induced by HIV-1 Tat. In conclusion, understanding of the role of ROS in Tat-mediated adhesion molecule expression and subsequent increased adhesion of monocyte to astrocyte provides a rationale for development of antioxidant compounds that may be useful as therapeutic agents for Tat-induced ROSassociated neurotoxicity.

\section{Acknowledgment}

This work was supported in part by a research grant from Korea Ministry of Health and Welfare (2002-2004), and in part by a Regional Innovation Center Grant from the Korean Ministry of Commerce, Industry and Energy, and in part by a research grant (HRF-2003-36) from Hallym University.

\section{References}

Aksenov MY, Hasselrot U, Bansal AK, Wu G, Nath A, Anderson $\mathrm{C}$, Mactutus CF, Booze RM. Oxidative damage induced by the injection of HIV-1 Tat protein in the rat striatum. Neurosci Lett 2001;305:5-8

Brenneisen P, Sies H, Scharffetter-Kochanek K. Ultraviolet-B irradiation and matrix metalloproteinases: from induction via signaling to initial events. Ann N Y Acad Sci 2002;973:31-43

Choi C, Kutsch O, Park J, Zhou T, Seol DW, Benveniste EN. Tumor necrosis factor-related apoptosis-inducing ligand induces caspase-dependent interleukin-8 expression and apoptosis in human astroglioma cells. Mol Cell Biol 2002; 22:724-36

Choi JS, Choi YJ, Park SH, Kang JS, Kang YH. Flavones mitigate tumor necrosis factor-alpha-induced adhesion molecule upregulation in cultured human endothelial cells: role of nuclear factor-kappa B. J Nutr 2004;134:1013-9

Conant K, Ma M, Nath A, Major EO. Extracellular human immunodeficiency virus type 1 Tat protein is associated with an increase in both NF-kappa B binding and protein kinase $C$ activity in primary human astrocytes. J Virol 1996;70:1384-9

Cross AR, Jones OT. The effect of the inhibitor diphenylene iodonium on the superoxide-generating system of neutrophils. Specific labelling of a component polypeptide of the oxidase. Biochem J 1986;237:111-6

D'Aversa TG, Yu KO, Berman JW. Expression of chemokines by human fetal microglia after treatment with the human immunodeficiency virus type 1 protein Tat. J Neurovirol 2004; 10:86-97

Dhawan S, Singh S, Aggarwal BB. Induction of endothelial cell surface adhesion molecules by tumor necrosis factor is blocked by protein tyrosine phosphatase inhibitors: role of the nuclear transcription factor NF-kappa B. Eur J Immunol 1997;27:2172-9

Dong Y, Benveniste EN. Immune function of astrocytes. Glia 2001;36:180-90

Doussiere J, Vignais PV. Diphenylene iodonium as an inhibitor of the NADPH oxidase complex of bovine neutrophils. Factors controlling the inhibitory potency of diphenylene iodonium in a cell-free system of oxidase activation. Eur J Biochem 1992; 208:61-71

Ensoli B, Buonaguro L, Barillari G, Fiorelli V, Gendelman R, Morgan RA, Wingfield P, Gallo RC. Release, uptake, and effects of extracellular human immunodeficiency virus type 1 Tat protein on cell growth and viral transactivation. J Virol 1993;67:277-87

Flohe L, Brigelius-Flohe R, Saliou C, Traber MG, Packer L. Redox regulation of NF-kappa $B$ activation. Free Radic Biol Med 1997;22:1115-26

Hudson L, Liu J, Nath A, Jones M, Raghavan R, Narayan O, Male D, Everall I. Detection of the human immunodeficiency virus regulatory protein tat in CNS tissues. J Neurovirol 2000;6:145-55

Kim, DS, Han, JH, Kwon HJ. NF-kappaB and c-Jun-dependent regulation of macrophage inflammatory protein-2 gene 
expression in response to lipopolysaccharide in RAW 264.7 cells. Mol Immunol 2003;40:633-43

Langford D, Masliah E. Crosstalk between components of the blood brain barrier and cells of the CNS in microglial activation in AIDS. Brain Pathol 2001;11:306-12

Lee H, Ryu J, Kim KA, Lee KS, Lee JY, Park JB, Park J, Choi SY. Transduction of yeast cytosine deaminase mediated by HIV-1 Tat basic domain into tumor cells induces chemosensitivity to 5-fluorocytosine. Exp Mol Med 2004;36:43-51

Lee SJ, Hou J, Benveniste EN. Transcriptional regulation of intercellular adhesion molecule-1 in astrocytes involves NFkappaB and C/EBP isoforms. J Neuroimmunol 1998;92: 196-207

Mollace V, Nottet HS, Clayette P, Turco MC, Muscoli C, Salvemini D, Perno CF. Oxidative stress and neuroAIDS: triggers, modulators and novel antioxidants. Trends Neurosci 2001;24:411-6

Morrow CD, Park J, Wakefield JK. Viral gene products and replication of the human immunodeficiency type 1 virus. Am J Physiol 1994;266:C1135-56

Ozdener H. Molecular mechanisms of HIV-1 associated neurodegeneration.. J Biosci 2005;30:391-405

Park J, Lee H, Lee Y, Kang YH, Rhim H, Choi SY. Expression of human immunodeficiency virus type 1 Tat proteins in Escherichia coli and application to study Tat functions. J Biochem Mol Biol 2000;33:337-43

Park J, Kwon D, Choi C, Oh JW, Benveniste EN. Chloroquine induces activation of nuclear factor-kappaB and subsequent expression of pro-inflammatory cytokines by human astroglial cells. J Neurochem 2003;84:1266-74

Park J, Choi K, Jeong E, Kwon D, Benveniste EN, Choi C. Reactive oxygen species mediate chloroquine-induced expression of chemokines by human astroglial cells. Glia 2004; $47: 9-20$

Pocernich CB, Sultana R, Mohmmad-Abdul H, Nath A, Butterfield DA. HIV-dementia, Tat-induced oxidative stress, and antioxidant therapeutic considerations. Brain Res Brain Res Rev 2005;50:14-26

Pu H, Tian J, Flora G, Lee YW, Nath A, Hennig B, Toborek M. HIV-1 Tat protein upregulates inflammatory mediators and induces monocyte invasion into the brain. Mol Cell Neurosci 2003;24:224-37

Rappaport J, Joseph J, Croul S, Alexander G, Del Valle L, Amini S, Khalili K. Molecular pathway involved in HIV-1- induced CNS pathology: role of viral regulatory protein, Tat. J Leukoc Biol 1999;65:458-65

Rumbaugh JA, Nath A. Developments in HIV neuropathogenesis. Curr Pharm Des 2006;12:1023-44

Schulze-Osthoff K, Bauer MK, Vogt M, Wesselborg S. Oxidative stress and signal transduction. Int $\mathrm{J}$ Vitam Nutr Res 1997;67:336-42

Seilhean D, Dzia-Lepfoundzou A, Sazdovitch V, Cannella B, Raine CS, Katlama C, Bricaire F, Duyckaerts C, Hauw JJ. Astrocytic adhesion molecules are increased in HIV-1-associated cognitive/motor complex. Neuropathol Appl Neurobiol 1997;23:83-92

Sen CK, Packer L. Antioxidant and redox regulation of gene transcription. FASEB J 1996;10:709-20

Watson K, Edwards RJ. HIV-1-trans-activating (Tat) protein: both a target and a tool in therapeutic approaches. Biochemical Pharmacology 1999;58:1521-8

Weiss JM, Nath A, Major EO, Berman JW. HIV-1 Tat induces monocyte chemoattractant protein-1-mediated monocyte transmigration across a model of the human blood-brain barrier and up-regulates CCR5 expression on human monocytes. J Immunol 1999;163:2953-9

Westendorp MO, Shatrov VA, Schulze-Osthoff K, Frank R Kraft M, Los M, Krammer PH, Droge W, Lehmann V. HIV-1 Tat potentiates TNF-induced NF-kappa B activation and cytotoxicity by altering the cellular redox state. EMBO J 1995; 14:546-54

Wiley CA, Baldwin M, Achim CL. Expression of HIV regulatory and structural mRNA in the central nervous system. AIDS 1996;10:843-7

Woodman SE, Benveniste EN, Nath A, Berman JW. Human immunodeficiency virus type 1 TAT protein induces adhesion molecule expression in astrocytes. J Neurovirol 1999;5: 678-84

Wu DT, Woodman SE, Weiss JM, McManus CM, D'Aversa TG, Hesselgesser J, Major EO, Nath A, Berman JW. Mechanisms of leukocyte trafficking into the CNS. J Neurovirol 2000;6: S82-5

Zhang SY, Park KW, Oh S, Cho HJ, Cho HJ, Park JS, Cho YS Koo BK, Chae IH, Choi DJ, Kim HS, Lee MM. NF-kappaB decoy potentiates the effects of radiation on vascular smooth muscle cells by enhancing apoptosis. Exp Mol Med 2005; $37: 18-26$ 